\title{
プロトン性溶媒および塩基性溶媒に対する二酸化イオウの溶解度 $*_{1}, *_{2}$
}

\author{
（炤和 42 年 10 月 30 日受理）
}

佐 野寛. 中本芳 枝*3

プロトン性溶媒および塩基性溶媒に対する二酸化イオウの溶解度を測定，比較した。プロトン性溶媒は水素結合による溶媒間の 自己会合のため二酸化イオウ溶解度が低く，水酸基の存在はしばしば溶解度に負の寄与をする。しかし分子内水素結合や 2 分子会 合によって水装結合部分の封鎖が起こる溶媒は溶解度が高い。プロトン性溶媒自身の酸強度と二酸化イオウ溶解度との関係は見い だすことができない。

塩基性溶媒は高い溶解度を示し，二酸化イオウ：溶媒分子モル比は 1 を越すものが多く，最高は 2 に達する。これを単純な溶解 と見なすことはできないが，1：1 付加物または 2:1 付加物の生成はまず確定的でない。

\section{1 緒言}

プロトン性溶媒および塩基性溶媒は，二酸化イオウに対して化 学的に活性であり，前報の非プロトン溶媒など不活性溶媒と区別 して扱う必要がある。

プロトン性溶媒の多くは, 部分的に二酸化イオウに付加溶解し $\tau$

$$
\begin{aligned}
& \mathrm{SO}_{2}+2 \mathrm{H}_{2} \mathrm{O} \rightleftarrows \mathrm{HOSO}_{2}^{-}+\mathrm{H}_{3} \mathrm{O}^{+} \\
& \mathrm{SO}_{2}+\mathrm{ROH} \rightleftarrows \mathrm{ROSOOH}^{1)}
\end{aligned}
$$

のような平衡を持つことができる。この反応は溶媒の酸塩基性強 度に関係すると考元られるから，溶媒の酸強度と二酸化イオウ溶 解度との関係を検討した。さらに，プロトン性溶媒の多くは溶媒 相互が強く会合し，水素結合が二酸化イオウ溶解を妨げると考え られる。したがって，溶媒の水素結合性が，溶解度に対しどれほ ど負の要因になっているか検討が必要である。

塩基性溶媒は二酸化イオウと作用して，種々の説はある233) が， およそつぎのように

$$
\begin{aligned}
& \left.\mathrm{SO}_{2}+\mathrm{NR}_{3} \rightleftarrows \mathrm{R}_{3} \mathrm{~N} \cdot \mathrm{SO}_{2}{ }^{4}\right) \\
& \mathrm{SO}_{2}+\mathrm{R}_{2} \mathrm{NH} \rightleftarrows\left(\mathrm{R}_{2} \mathrm{NH} \cdot \mathrm{SO}_{2}\right)_{2}{ }^{5}
\end{aligned}
$$

Lewis 酸中和反応を起こして，1:1 の Lewis 酸塩を形成すると するものが多い。塩基性溶媒の溶解度が，これらの説の範囲にあ るかどうかを検討する。

\section{2 実験}

二酸化イオウの溶媒に対する溶解度測定は，吸収ガス容積をは かる吸収法および通気後溶媒中の溶存量を滴定する通気法の二法 を用い，それぞれ $30^{\circ} \mathrm{G} ， 1 \mathrm{~atm}$ に打ける值を求めた。測定操作， 測定装置および計算は前報のと括りである。

*1 この報交を“二酸化イオウの溶解度(第 2 報)”とする.

*2 前報(第 1 報)，佐野 寛，日化，89，362(1968)。

*3 Hiroshi Sano, Yoshie Nakamoto 大阪工業技術試験所, 池田市緑丘

1）畑 哲夫, 東北大非水研報, 10, 14(1961).

2) P. Walden, M. Centnerszwer, Z. Phys. Chem., 43, 385 (1903).

3) K. Wickert, G. Jander, Ber., 70, 251 (1937).

4) L. C. Bateman, E. P. Hughes, C. K. Ingold, J. Chem. Soc. (London), 1944, 243.

5) J. Makaranzy, B. Mohai, Veszpremi Vegyip. Egyet. Kozleme., 6, 183(1962); Chem. Abst., 58, $6252 \mathrm{~d}(1962)$.

\section{3 結果と考察}

\section{1 高粘性および固結性溶媒への溶解度}

3.1 .1 グリセリンとフェノール：グリセリンは非常に粘度が 高く, 容易に平衡に到達しないのでエタノール溶液から外挿した (図 1)。フェノールは常温では固体であるが， $60^{\circ} \mathrm{C}$ に加熱して 液体として二酸化イオウを吸収させながら $30^{\circ} \mathrm{G}$ 一冷却すると， フェノールの融点が降下して，30 $\mathrm{C}$ に㧅いて液状のまま測定を することができた。

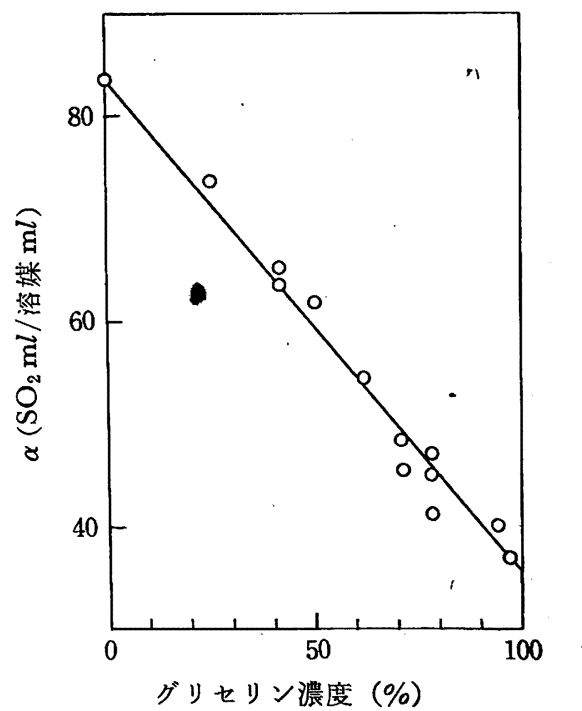

図 1 グリセリンのエタノール溶液への二酸化イオウ溶解度

3.1 .2 ピリジンおよび第三アミン：ピリジンおよび第三アミ ンのように活性水素を持たない塩基は二酸化イオウを等モル以上 吸収しても固結しないが，非常に高粘度となる。不活性溶媒，た とえばトルエンに溶解した溶液は，いずれも50\% 付近より高濃 度では二酸化イオウを吸収するとともに沈殿が析出し測定できな い。したがって $100 \%$ 浱度への外插は困難であった。そこでこれ らの溶媒は，より測定の容易な高温側からの外择を行なう(区 2)。30 $\mathrm{C}$ 付近の低温では高粘度のため測定值のばらつきが大き くなるが，高温側の值を延長して容易に $30^{\circ} \mathrm{C}$ における值をきめ ることができる。 
$t\left({ }^{\circ} \mathrm{C}\right)$

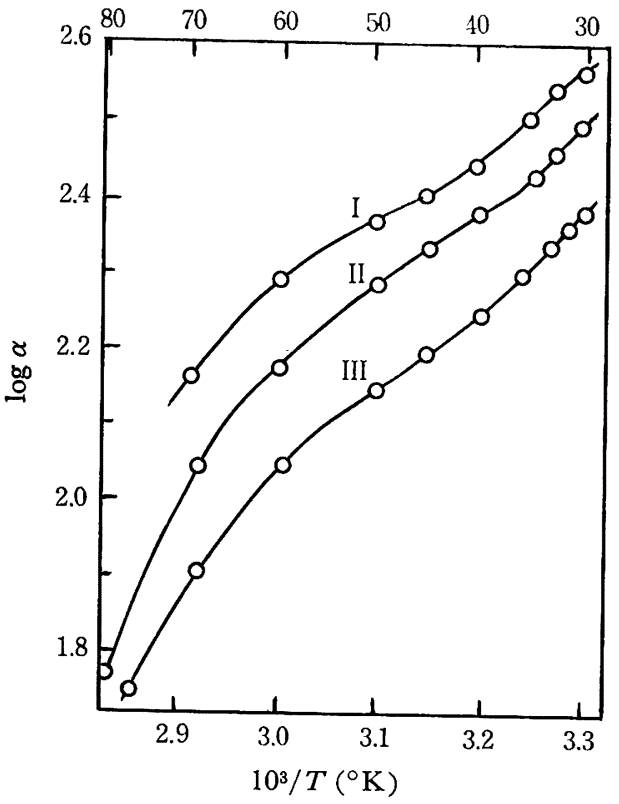

I : ピリジン, II: ピコリン, III: キノリン

図 2 ピリジン系溶媒への二酸化イオウ溶解度の温度依存性

3.1.3 アミン系溶媒： $\mathrm{R}-\mathrm{NH}_{2}$ 型のアミンはすべて二酸化イオ ウを吸って完全に固化する。高温からの外挿も $50^{\circ} \mathrm{C}$ 前後で固化 するので不正確であるが，固化温度以下でも吸収時間を長くとれ ぼ測定值が高温側からの延長線上にくるので，その值を採用する （図 3)。この場合, 誤差範囲は $5 \%$ 程度になる。沸点の低い $n$-ブ チルアミンはトルエン溶液から外挿したが，60\% 以上の浱度の測

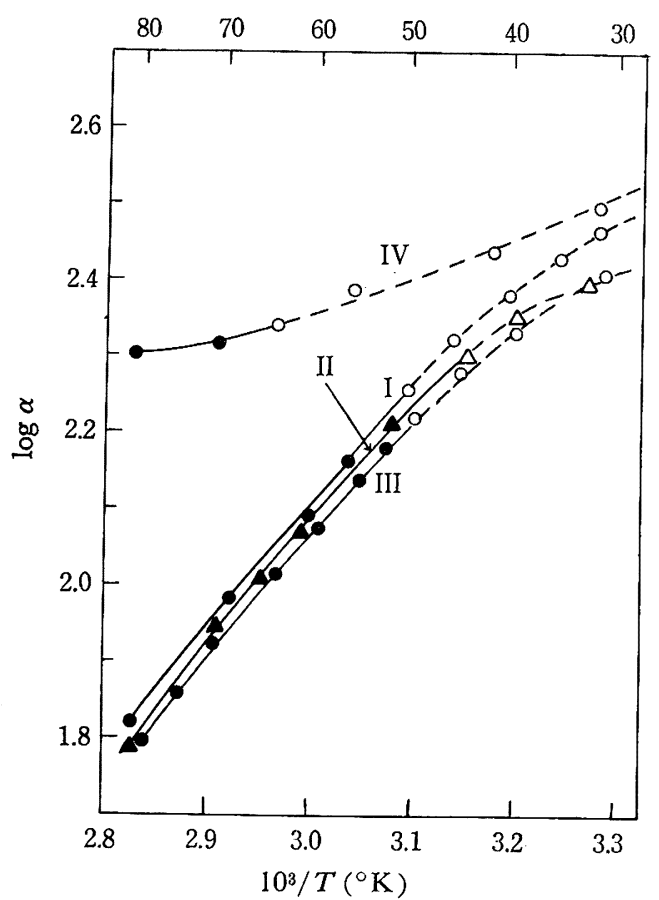
I : フニリン,
II : トルイジン
直：キシリジン,
IV : ペンジルアミン
吸収後液状,
$\mathrm{O}$ : 吸収後固化

因 3 フミン系溶媒への二酸化イオウ溶解度の温度依存性
定は高粘度のため得られない少裖度 $100 \%$ への外捕値(図 4)の 估制は低い。エタノールアミンは，卜ルエンなどの不活性溶媒 に浴けず，固化温度も高く高洫からの外雨も困難であり，エタ， 一ル溶液で外㨂(図4)を試多たが $50 \%$ 付近で沈殿が発生し，さ らに不活性溶媒溶液以外に执いては直線外雨が期待できないので 外挿値の精度はきわめて悪い。

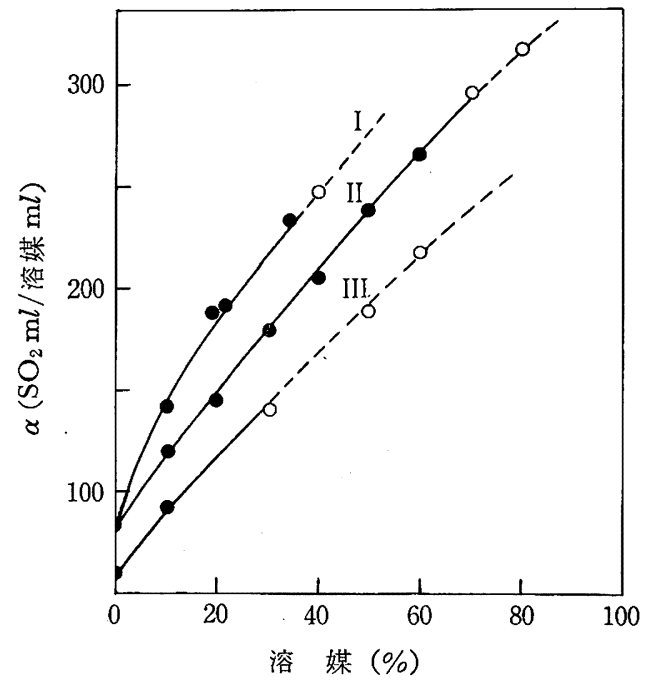

I：モノエタノールフミンのエタノール溶液

II : $n$-ブチルアミンのエタノール溶液

III : $n$-ブチルアミンのトルェン溶液

○：吸収後液状，○：吸収後固化

図4 n-ブチルアミンおよびモノェタノールフミンの 溶液一の二酸化イオウ溶解度

\section{2 結 果}

測定結果を表 1 によとめる。吸収法および通気法による結果， $\alpha_{0}$ および $\alpha_{l}$ は全般的には一致しているが，揮発性の大きな溶媒 ほど通気法の結果は再現性が恶く，通気による溶媒の移動のため とみられる。さらに，塩基性溶媒においては，流動性がとぼしく なるので通気法は実施できなくなる。したがって，以後の考察に は吸収法の結果を使用することとする。

吸収法による值 $\alpha_{0}$ は，一般に $0.5 \%$ までの範囲で再現性があ るが，外挿によって求められた $\alpha_{0}$ 值は信頼性が低いものがあり, 表 1 にはとの変動範囲も示した。

水への溶解度測定值はきわ姼く67), 水のBunsen 吸収係数 $28.3\left(30^{\circ} \mathrm{C}\right)$ を測定法の精度の検查に使用した。メタノール，工 タノールの重量パーセントによる測定值738) から Bunsen 吸収係 数に換算し，さらにこれを $30^{\circ} \mathrm{C}$ に外挿すると $124 ， 91.5$ が得ら れ，表 1 の值との一致はあまりよくないが，これは外插による精 度の低さを示すとみられる。塩基性溶媒については，工業的にス ルフィジン法などで二酸化イオウ吸収に使用されており，関連す る測定值はきわめて多い910)が，これらの值はいずれも二酸化イ

6) A. E. MarKham, K. A. Kobe, Chem. Rev., 28, 519 (1941).

7）日本化学会編，“化学便覧基礎編”，丸善(1966)p. 620.

8) Lobry de Bruyn, Z. Physik. Chem., 10, 782(1892).

9) M. Katz, R. J. Cole, Ind. Eng. Chem., 42, 2258(1950); E. P. Fleming, T. C. Fitt, ibid., 42, 2253 (1950).

10) V. F. Postnikov, T. I. Kunin, Trans. Inst. Chem. Tech. Ivanovo (USSR), 1939, 56; Chem. Abst., 33, 8127 b(1937). 
裴 1 二酸化イオウ溶解度測定值 $\left(30^{\circ} \mathrm{C}\right)$

溶 媒

\begin{tabular}{|c|c|c|c|c|c|}
\hline 水 & 29.8 & 0.040 & 28.3 & 24.5 & 25.6 \\
\hline 硫 & 21.2 & 0.000 & 19.2 & 19.2 & 19.2 \\
\hline エチレングリコール & 59.2 & 0.000 & 53.9 & 51.8 & 51.8 \\
\hline ジェチレングリコール & 130 & 0.000 & 119 & 119 & 119 \\
\hline ブロビレングリコール & 68.0 & 0.000 & 61.9 & 61.7 & 61.7 \\
\hline グリセリン & & & $57.5^{c)}$ & & \\
\hline 酸 & 61.2 & 0.040 & 57.8 & 55.5 & 60.0 \\
\hline ホルムアミド & 175.2 & 0.001 & 160.0 & 158.0 & 159.2 \\
\hline メタノール & 116.2 & 0.125 & 122.1 & 99.9 & 124.5 \\
\hline エタノール & 88.1 & 0.069 & 85.9 & 75.9 & 84.0 \\
\hline ーブロパノール & 53.9 & 0.035 & 50.7 & 48.6 & 52.6 \\
\hline$t$ ーブチルフルコール & 47.9 & 0.041 & 45.7 & 42.2 & 45.4 \\
\hline ーブタノール & 53.8 & 0.008 & 45.5 & 48.4 & 49.2 \\
\hline イソフミルアルコール & 40.9 & 0.006 & 37.4 & 37.3 & 37.5 \\
\hline 1ーヘキサノール & 41.5 & 0.004 & 37.9 & 37.6 & 37.7 \\
\hline ルクロヘキサノール & 38.0 & 0.001 & 34.6 & 34.3 & 34.3 \\
\hline ーオクタノール & 28.7 & 0.000 & 26.1 & 25.5 & 25.5 \\
\hline ペンジルフルコール & 66.3 & 0.000 & 60.3 & 59.5 & 59. \\
\hline $\begin{array}{l}\text { テトラヒドロ } \\
\text { フルフリルフルコール }\end{array}$ & 184 & 0.001 & 167 & 165.8 & 160 \\
\hline フルフリルアルコール & 96 & 0.001 & $86^{d)}$ & & \\
\hline 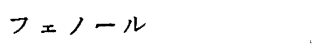 & 75.1 & 0.000 & 68.6 & 68.1 & 68.1 \\
\hline ○ークロルフェノール & 76.2 & 0.000 & 69.4 & & \\
\hline o-クレゾール & 75.0 & 0.000 & 68.3 & 68.0 & 68.0 \\
\hline グフヤコール & 108.0 & 0.000 & 98.4 & & \\
\hline サリチル酸メチル & 84.3 & 0.000 & 76.7 & & \\
\hline 酸 & 106.0 & 0.010 & 97.4 & 95.2 & 96.2 \\
\hline プロピオン酸 & 75.7 & 0.004 & 69.0 & & \\
\hline カプロン酸 & 37.0 & 0.000 & 33.5 & 33.0 & 33.0 \\
\hline メチルセロソルブ & 201.0 & 0.008 & 184.2 & 185.1 & 186.9 \\
\hline ブチルセロソルブ & 113.5 & 0.001 & 103.2 & 103.6 & 103.7 \\
\hline ブェニルセロソルブ & 96.1 & 0.000 & 87.5 & & \\
\hline nーブチルアミン & & & $350>c)$ & & \\
\hline モノェタノールアミン & & & $380>c)$ & & \\
\hline $\boldsymbol{ア}=リ ン$ & & & $\left.274^{b}\right)$ & & \\
\hline 混合 $\left(o^{-}, m-, p-\right)$ トルイジ & & & $241^{b)}$ & & \\
\hline 混合キシリジン & & & $234^{b)}$ & & \\
\hline ベンジルアミン & & & $\left.288^{b}\right)$ & & \\
\hline ジメチルアニリン & 280 & 0.000 & 254 & & \\
\hline トリブチルフミン & 206.1 & 0.000 & 187.5 & & \\
\hline ピリジン & & & $424^{a)}$ & . & \\
\hline 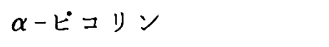 & & & $335.5^{a)}$ & & \\
\hline 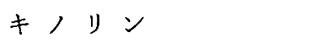 & & & $229.5^{a)}$ & & \\
\hline
\end{tabular}

注 $a$ ）高温から外挿. b) 高温から外挿, $30^{\circ} \mathrm{C}$ では固化.

c) 希薄溶液加ら外捚. $d$ ) 樹脂状物質析出.

$v$ : 吸収法による測定值, 測容器 $27^{\circ} \mathrm{C}(\mathrm{ml} /$ 溶媒 $\mathrm{ml})$.

$P_{s}: 30^{\circ} \mathrm{C}$ における溶媒蒸気压 $(\mathrm{atm})$.

$\alpha_{v}$ : 吸収法によるBunsen 吸収係数 $(\mathrm{m} l /$ 溶媒 $\mathrm{m} l)$.

$l$ : 通気法による測定值 $(\mathrm{m} l /$ 溶媒 $\mathrm{m} l)$.

$\alpha_{l}$ : 通気法による Bunsen 吸収係数 $(\mathrm{ml} /$ / 溶媒 $\mathrm{m} l)$.

オウ分圧の非常に低い範囲で，おもに水との混合液に対して用い られているものであり，二酸化イオウ $1 \mathrm{~atm} \cdot$ 溶媒 $100 \%$ 一外雨 することは困難であり本報文に利用することができない。

\section{3 考 察}

3.3 .1 溶媒の酸強度と溶解度との関係：硫酸水溶液での実験 例1112)では，二酸化イオウ吸収は溶液の酸強度上閔係がなく， $\mathrm{H}_{2} \mathrm{SO}_{4} \cdot \mathrm{H}_{2} \mathrm{O}$ 組成のとき最小值があり，全城にわたって Henry
則によくしたがっている。そして二酸化イオウ分圧の低く水中の 二酸化イオウ濃度が小さいときは覀硫酸解離の影響が現われる18) が，本報の実験の範囲では解離溶解の影響は非常に小さい。

溶媒自身の酸性も，二酸化イオウ溶解度にまったく無関係であ ることが図 5 によって示される。溶媒の酸解離定数と溶解度との 相関は存在しない。

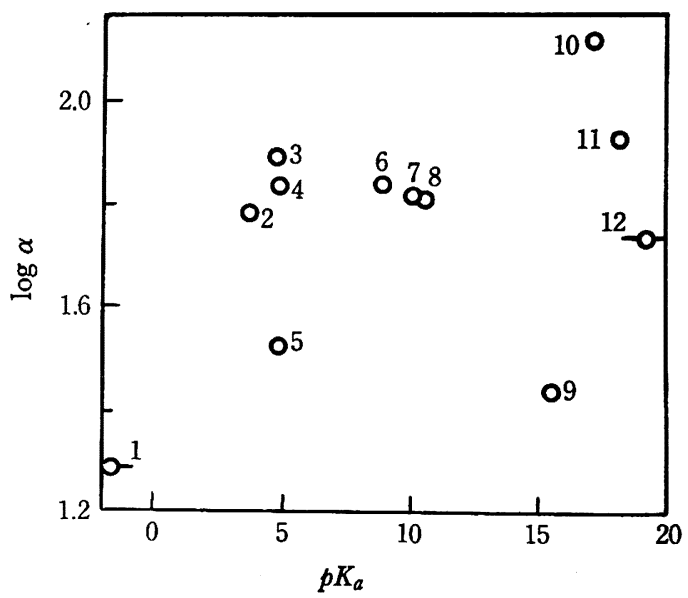

1: 硫酸, 2: ギ酸, 3: 酢酸, 4: プロビオン酸,

5: カプロン酸, 6: フェノール，7: ○-クロルフェノール,

8: o-クレゾール, 9: 水, 10: タタノール,

11: エタノール， 12: 2-プロパノール

図 5 溶媒の酸強度と二酸化イオウ溶解度

3.3 .2 透電定数と溶解度との関係：溶媒の透電定数と二酸化 イオウ溶解度との関係を図 6 に示す。1 価の直鎖アルコールだけ は線で連結してある。プロトン性溶媒においては，ROH 系列が

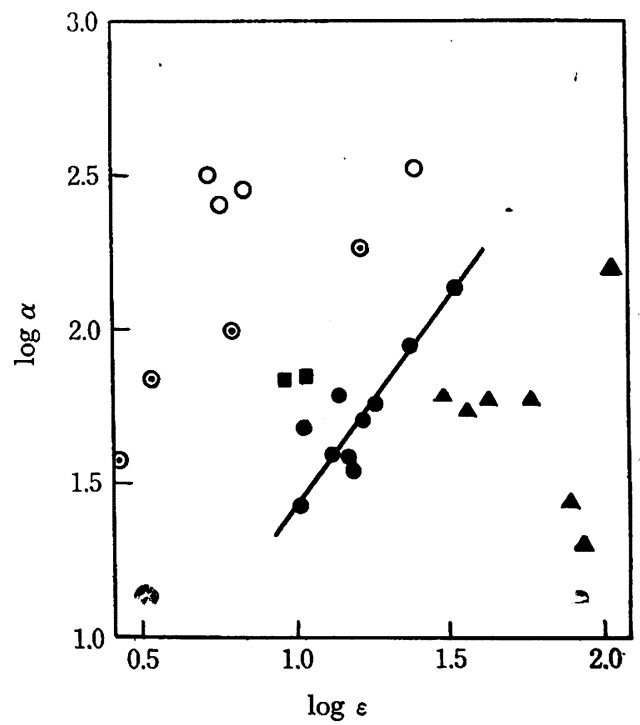

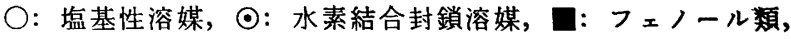

○：1価アルコール， $\boldsymbol{\Delta}$ ：多官能水素結合性溶媒

図 6 溶媒の透電定数と溶解度

11) D. A. Knzutsov, J. Chem. Ind. (USSR), 18, No. 22, 3 (1941); Chem. Abst., 38, 57146(1942).

12) V. Ĉupr, Rec. Trav. Chim., 47, 55(1928); Chem. Abst., 22, 12624(1926).

13）恩田格三郎，佐田栄三，川竹了，“分離技術 1.8”, 工 学書院 (1964)p. 27. 
ほぼ直線上に集まり，透電定数と溶解度との並行関係走示してい るように見える。直線の右下方に，透電定数が高く溶解度の低い グループがあり，これはおもにジオールや水などの多官能性水素 結合をもつ溶媒群である。直線の左上方には透電定数は小さいが 溶解度の高いグループがあり，カルボン酸(ギ酸を除く)やメチル セロソルブなどがある。これらの共通点は，二分子間または分子 内で水素結合が封鎖されていることにある。<smiles>[R]C(=O)OC=[R]C([R])O[Hg]OC([R])=O</smiles><smiles></smiles>

表 2 二酸化イオウのモル溶解度 $\left(30^{\circ} \mathrm{C}\right)$

\begin{tabular}{|c|c|c|c|}
\hline 溶 媒 & $\begin{array}{l}\text { 溶 媒 } \\
(\mathrm{mol} / l)\end{array}$ & $\begin{array}{l}\alpha / \text { 溶媒 } \\
1 \mathrm{~mol}\end{array}$ & $\begin{array}{l}\text { モル比 } \\
\left(\mathrm{SO}_{2} / \text { 溶媒 }\right.\end{array}$ \\
\hline （I 族） & & & \\
\hline 水 & 55.2 & 0.51 & 0.023 \\
\hline 酸 & 18.7 & 1.03 & 0.046 \\
\hline$\neq$ & 26.2 & 2.30 & 0.103 \\
\hline グリセリン & 13.6 & 4.22 & 0.188 \\
\hline エチレングリコール & 17.8 & 3.02 & 0.135 \\
\hline ジェチレングリコール & 10.6 & 11.2 & 0.500 \\
\hline プロピレングリュール & 13.6 & 4.56 & 0.204 \\
\hline $\begin{array}{l}\text { ホルムフミド } \\
(\mathbb{I} \text { 族 })\end{array}$ & 25.0 & 6.41 & 0.286 \\
\hline メタノール & 24.5 & 5.39 & 0.241 \\
\hline エタノール & 16.5 & 5.08 & 0.227 \\
\hline 2-プロパノール & 12.9 & 4.12 & 0.184 \\
\hline$t$-ブチルフルコール & 10.9 & 4.28 & 0.191 \\
\hline 1-ブタノール & 10.8 & 4.54 & 0.203 \\
\hline イソフミルフルコール & 9.11 & 4.11 & 0.183 \\
\hline 1ーヘキサノール & 7.98 & 4.75 & 0.212 \\
\hline シクロへキサノール & 9.61 & 3.60 & 0.160 \\
\hline 1-オクタノール & 6.35 & 4.11 & 0.183 \\
\hline ペンジルフルコール & 9.63 & 6.26 & 0.280 \\
\hline 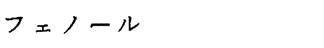 & 11.2 & 6.13 & 0.273 \\
\hline o-クレゾール & 9.69 & 7.05 & 0.315 \\
\hline ( III 族) & & & . \\
\hline 酢酸 & 17.3 & 5.63 & 0.251 \\
\hline プロピオン酸 & 13.3 & 5.19 & 0.232 \\
\hline カプロン酸 & 7.99 & 4.19 & 0.187 \\
\hline メチルセロソルブ & 12.6 & 14.6 & 0.652 \\
\hline ブチルセロソルブ & 7.61 & 13.6 & 0.605 \\
\hline フェニルセロソルブ & 7.95 & 11.0 & 0.491 \\
\hline $\begin{array}{l}\text { テトラヒドロ } \\
\text { フルフリルナルコール }\end{array}$ & 10.3 & 16.2 & 0.724 \\
\hline フルフリルフルコール & 11.5 & 7.5 & 0.335 \\
\hline oークロルフェノール & 9.60 & 7.23 & 0.323 \\
\hline グフヤコール & 8.98 & 10.96 & 0.489 \\
\hline 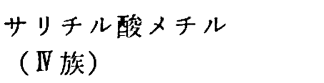 & 7.77 & 9.87 & 0.441 \\
\hline n-ブチルアミン & 10.0 & $35>$ & $1.6>$ \\
\hline モノエタノールフミン & 16.4 & $23>$ & $1.1>^{\circ}$ \\
\hline ベンジルアミン & 9.21 & 31.3 & 1.40 \\
\hline $\boldsymbol{T}=リ ン$ & 10.7 & 25.6 & 1.14 \\
\hline トルイジン & 9.4 & 25.7 & 1.15 \\
\hline キシリジン & 8.08 & 28.9 & 1.29 \\
\hline ジメチルフニリソ & 7.87 & 32.3 & 1.44 \\
\hline トリプチルフミン & 4.15 & 45.2 & 2.02 \\
\hline ピリジン & 12.3 & 34.5 & 1.54 \\
\hline$\alpha$ 一ヒンリン & 10.2 & 32.9 & 1.47 \\
\hline$\neq 1$ 人 リ & 8.45 & 27.2 & 1.21 \\
\hline
\end{tabular}

カルボン酸のうち，二量体となりにくいギ酸だけは直線の下方 に現われる。フェノール類はアルコール直線の上方に現われる が，これは水素結合の封鎖というよりも芳香族炭化水素の溶解度 值とほぼ同水準にある*4ことからみて芳香核の効果と考えられ る。アルコールのうち, ベンジルアルコールだけがフェノール群 の近傍にあることも同様に理解できる。

塩基性溶媒は誘電率にあまり関係なく上方へ集まっている。

3.3 .3 分子量と溶解度との関係：二酸化イオウ溶解度と分子 量との関係を図 7 に示す。この場合も，アルキル部分の増大によ

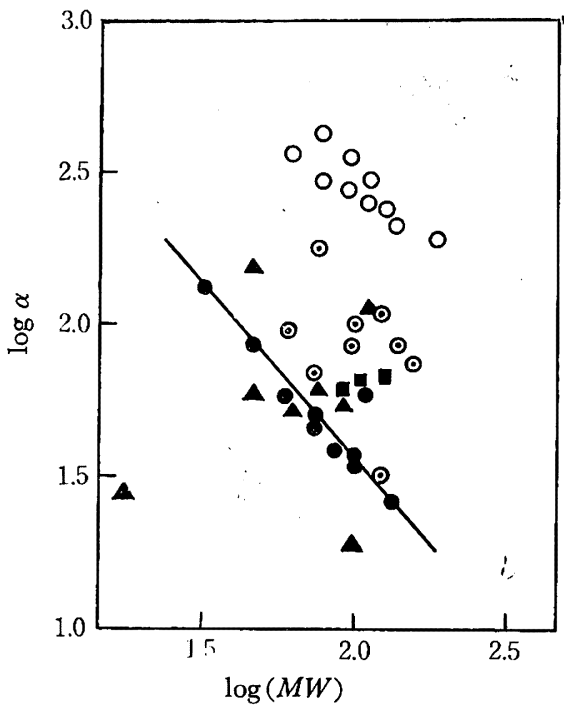

図中の記号は図 6 と同じ。

図 7 溶媒 の分子量と溶解度

る分子量の増加は, 誘電淘の減少をともなうので, 本質的に図 6 の関係と同じことが認められる。 ROH の直線の左下方に，水素 結合のより発達した溶媒が分布し，右上方には水素結合の封鎖さ れた溶媒が分布する。誘電率の不明なフルフリルアルコール，サ リチル酸メチルおよびセロソルブ類もここに分布しているからそ の水素結合は分子内封鎖されているものとみられる。

図 6 および図 7 から，本報で取り扱った溶媒は溶解性の増加の 順につぎのグループに大別される。

I 多官能水素結合性溶媒

II 一官能水素結合性溶媒

III 水絜結合封鎖溶媒

IV 熄基性溶媒

I の溶媒では，水素絬合が立体網状に連らなり，溶質分子を閉 め峌すが，Iの溶媒では水素結合は線状に発達するだけであり， さらに III溶媒では，会合ブロックごとに自由になるので，前報 におけるエーテル，エステルとほぼ同じ水準*5にまで溶解度が高 まる。

3.3 .4 官能基の寄与： 表 2 に各溶媒のモルあたりの溶解度を

*4 前報におけるベンゼンおよびアルキルベンゼンのモル溶 解度は 5〜7 $(\alpha / \mathrm{mol})$ でフェノール類の值(本報表 2$)$ と 同じ水準にある。

*5 前報におけるエーテルおよび酶酸エステルのモル溶解度 は，大きな立体障害のあるものを除くとほほ $11 〜 20(\alpha)$ $\mathrm{mol}$ ) であり，政（本報表 2 ）の值に近い, 


\section{計算して示す。}

これによると，モル溶解度は分子量の大小にあまり関係なく官 能基別にほぼ同じ水準にあり，より不活性な基の存在は大きな影 響を与えない。I 族の中でジェレングリコールのやや高い值は その水素結合が一部分，分子内水素結合として封鎖されているこ とを示すと見られる。したがって官能基の二酸化イオウ親和性の 定数は，水素結合の封鎖されたものと自由なものとを区別して評 価しなければならない。

表 3 官能基の二酸化イオウ親和系列と溶解定数 $\left(30^{\circ} \mathrm{C}\right)$

$\begin{array}{ll}\rightarrow \mathrm{N} & 2 \sim 1 \quad\left(\mathrm{SO}_{2} \text { モル/官能基当量 }\right) \\ \text { 分子内 } \mathrm{OH} \cdots \mathrm{O} & 0.7 \\ \text { 会合 } \mathrm{COOH} & 0.25 \\ \text { 自由 }-\mathrm{CH}_{2} \mathrm{OH} & 0.22 \sim-0.1 \\ \text { 自由 }-\mathrm{COOH} & 0.1\end{array}$

1 価アルコールとジオール，トリオールとの比較から，水酸基 の存在は他の二酸化イオウ親和基に対し負の親和性を意味するこ ととなり，一定の值を水酸基に与えることは困難である。したが って，I 族溶媒は前報*2 の飽和炭化水素と同じく筫溶媒ではある が，アルキル基の二酸化イオウ親和性が小さいために炭化水素の 溶解度が小さいのとはまったく性質を異にして，妨害的貧溶媒と
でもいうべきである。

塩基性溶媒においては，これらの二酸化イオウ溶解が単純な溶 解ではないことはさきの図 2 および図 3 において, $\log \alpha$ と $1 / T$ との関係が前報*2における化学的不活性溶媒におけるように直線 となっていないことからも知られる。また，いずれも等モルまた はそれ以上の二酸化イオウを吸収し，いちじるしく流動性を失な うことから考兵て，1：1 Lewis 酸塩の生成および溶媒和による 吸収との和を総吸収量と考えることが試みられる。しかし図 2 お よび図 3 においては，いずれも二酸化イオウ: 溶媒塩基の $1: 1$ 当量点で屈曲がほとんど認められないことから 1:1 Lewis 酸塩 の生成は支持されない。さらに等モル超過分の二酸化イオウ吸収 量は，単なる溶媒和溶解としてはあまりにむ大きすぎる*6。

二酸化イオウと塩基の $2: 1$ 付加物の生成を考慮することが必 要とみられるが，その構造や性質はまだ不明である。

(1967 年 4 月, 日本化学会第 20 年会 (一部) 発表)

*6 ピリジンは $1.5 \mathrm{~mol}$ の二酸化イオウを吸収するが，・ ンゼン核部分のモル溶解值は前報のデータによると 0.2 $\mathrm{mol}$ にすぎない. トリブチルアミンは $2.0 \mathrm{~mol}$ の二酸 化イオウを吸収するが 3 個のプチル基のモル溶解値の和 はわずか $0.12 \mathrm{~mol}$ にすぎない.

\section{カオリン釷物の水酸化ナトリウム処理によるホージャサイト型ゼオライトの合成*1, *2}

（昭 和 42 年 11 月 20 日 受理 )

高 橋浩*3 ·西 村 陽 一*4

ハロイサイトの水酸化ナトリウム処理によるホージャサイト型ゼオライトの生成およびその構造変化の過程をX線回折法，電子 顕微鏡法などによって研究した。

出発物質として結晶度のいちじるしく低いハロイサイトである伊那カオリン(長野県, 駒ケ根産)を用い, また試料の $\mathrm{SiO}_{2} / \mathrm{Al}_{2} \mathrm{O}_{3}$ モル比を高めるために水ガラスを加えた。混合試料は常圧のもとで水酸化ナトリウム溶液とともに加熱処理を行なった。

その構造変化の過程はつぎのとおりである。

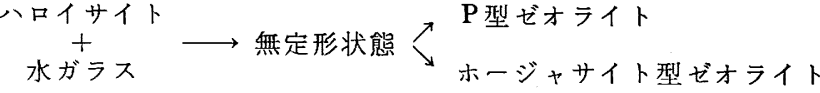

$$
\begin{aligned}
& \text { レ }
\end{aligned}
$$

水酸化ナトリウム処理によって，試料は無定形状態を経てホージャサイト型ゼオライトあるいは P 型ゼオライトに変化する。ま たホージャサイトは最終的にヒドロキシソーダライトに変化する。

ホージャサイトあるいは P 型ゼオライトのいずれが生成するかはアルカリ量, アルカリ濃度に依存する。アルカリ量の多い場合 にはアルカリ濃度の低い条件で，またアルカリ量の少ない場合には，アルカリ濃度の高い条件でホージャサイトは生成し，その他 の条件では P 型ゼオライトのみが生成する。

\section{1 緒言}

著者らはさきに結晶度の異なる数種のカオリン鉱物およびアロ フェンを出発物質として，これらの水酸化ナトリウム処理による A 型ゼオライトへの構造变化について報告した。すなわちカオリ

*1この報文を“ゼオライトの研究(第 2 報)”とする.

*2 前報(第 1 報)，高橋 浩，西村陽一，日化，88，528 (1967).

*3 Hiroshi TAKAHAsHI 東京大学理学部化学教室, 東京都 交京区本郷

*4 Yôichi Nishimura 東京大学生产技術研究所, 東京都港 区六本木
ン鉱物は水酸化ナトリウム処理によって最終的にはヒドロキシソ 一ダライト(hydroxy sodalite)に変化するが，結晶度のいちじる しく低いハロイサイト(halloysite)やアロフェン(allophane)の場 合には，適当な条件のもとで分子ふるい作用を有するゼオライト である A 型ゼオライト(zeolite type A)の生成の過程をともなう ことを見い忘し，さらにカオリン鉱物を出発物質とするA型ゼオ ライトの生成機構を明らかにしたり。

本研究においては, 結晶度のいちじるしく低いハロイサイトを

1）前報(第 1 報)，高橋 浩，西村陽一，日化，88，528 (1967). 